\title{
MANAJEMEN PEMBELAJARAN TAHFIDZ AL-QUR'AN BERBASIS METODE TALAQQI
}

\section{Tika Kartika}

Universitas Islam Negeri Sunan Gunung Djati Bandung

Jl. A.H. Nasution No 105 Cibiru Bandung

Email: tikakartikampi@gmail.com

\begin{abstract}
ABSTRAK
Pondok Pesantren Al-Hikamussalafiyah merupakan pondok pesantren yang memfokuskan pada Tahfidz Al-Qur'an, peneliti menemukan adanya manajemen pembelajaran Tahfidz Al-Qur'an berbasis metode Talaqqi yang mengakibatkan santri mencapai target hafalannya. Penelitian ini bertujuan untuk mengetahui manajemen pembelajaran Tahfidz Al-Qur'an berbasis metode Talaqqi di Pondok Pesantren Al-Hikamussalafiyah Kabupaten Sumedang yang meliputi perencanaan, pengorganisasian, kepemimpinan, dan evaluasi pembelajaran. Penelitian ini menggunakan pendekatan kualitatif dan metode penelitian deskriptif. Teknik pengumpulan data meliputi teknik observasi, wawancara dan studi dokumentasi. Hasil penelitian menunjukan bahwa Pondok Pesantren AlHikamussalafiyah telah melaksanakan manajemen pembelajaran yang meliputi (1) perencanaan pembelajaran Tahfidz Al-Qur'an berbasis metode talaqqi meliputi: pertama, menentukan target hafalan santri; kedua, menentukan strategi dan metode pembelajaran; ketiga, menentukan program kegiatan pembelajaran; keempat, menentukan jadwal dan waktu pembelajaran. (2) Pengorganisasian pembelajaran Tahfidz Al-Qur'an berbasis metode talaqqi dilaksanakan untuk menentukan struktur dan tugas ustadz/ustadzah serta mekanisme pembelajaran Tahfidz Al-Qur'an. (3) Kepemimpinan pembelajaran Tahfidz Al-Qur'an berbasis metode talaqqi dilakukan ustadz/ustadzah agar pelaksanaan pembelajaran berjalan secara kondusif, yang meliputi pengelolaan kelas dan kegiatan pembelajaran. (4) Evaluasi pembelajaran Tahfidz Al-Qur'an berbasisi metode talaqqi dengan melihat hasil belajar santri serta kemampuan santri sesuai indikator yang telah ditentukan pihak pesantren.
\end{abstract}

Kata Kunci: manajemen, pembelajaran, tahfidz Al-Qur'an, talaqqi.

\section{ABSTRACT}

Al-Hikamussalafiyah Islamic Boarding School is an Islamic boarding school which focuses on tahfidz al-quran, the researchers found the management of Tahfidz Al-Qur'an learning based on the Talaqqi method which resulted in students achieving their memorization targets. This study aims to determine Tahfidz Al-Qur'an's Learning Management based on the Talaqqi method in the 
Al-Hikamussalafiyah Islamic Boarding School in Sumedang Regency which includes planning, organizing, leadership, and evaluating learning. This study uses a qualitative approach and descriptive research methods. Data collection techniques include observation techniques, interviews and documentation studies. The results showed that the Al-Hikamussalafiyah Islamic Boarding School had implemented learning management which included (1) Tahfidz AlQur'an learning planning based on the talaqqi method including: first, determining the target of memorizing students; second, determine learning strategies and methods; third, determine the program of learning activities; fourth, determine the schedule and learning time. (2) Organizing the learning of tahfidz al-quran based on the talaqqi method is carried out to determine the structure and tasks of the theacer and the learning mechanism of the Tahfidz Al-Qur'an. (3) The leadership of tahfidz Al-Qur'an learning based on the talaqqi method is done by the theacer in order that the learning implementation runs conductively, which includes classroom management and learning activities. (4) Evaluation of learning tahfidz al-quran based on the talaqqi method by looking at the learning outcomes of students and the ability of students according to the indicators determined by the pesantren.

Keywords: Management, learning, Tahfidz Al-Qur'an, Talaqqi

\section{PENDAHULUAN}

Konsep manajemen pembelajaran memiliki arti luas dan arti sempit, Manajemen pembelajaran dalam arti luas merupakan kegiatan mengelola bagaimana membelajarkan si pembelajar dari proses perencanaan, pengorganisasian, pengarahan atau pengendalian, dan penilaian. Sedangkan manajemen pembelajaran dalam arti sempit merupakan kegiatan yang perlu dikelola oleh guru pada saat terjadinya proses interaksi dengan siswa dalam pelaksanaan pembelajaran (Rukajat, 2018, hlm. 5).

Manajemen pembelajaran merupakan kegiatan yang dimulai dari perencanaan, pengorganisasian, pengarahan dan penilaian pelaksanaan pembelajaran agar mencapai hasil belajar yang lebih efektif dan efisien. Manajemen pembelajaran mencakup saling hubungan berbagai peristiwa tidak hanya seluruh peristiwa pembelajaran dalam proses pembelajaran tetapi juga faktor logistik, sosiologis dan ekonomis. Karena sistem manajemen pembelajaran adalah berkenaan dengan teknologi pendidikan yang mana teknologi adalah organisasi terpadu dan kompleks dari manusia, mesin, gagasan, prosedur dan manajemen. Jadi teori pembelajaran, pengajaran, manajemen pembelajaran adalah ilmu murni, terapan dan sistem. Teori pembelajaran melintasi teori pengajaran yang didalamnya dihubungkan berbagai faktor ke dalam sistem manajemen pembelajaran (Syafaruddin \& Nasution, 2005, hlm. 76-77).

Manajemen pembelajaran lebih sempit dari pada sekedar administrasi pendidikan, karena kegiatan ini menangani satu program pengajaran dalam institusi pendidikan. Manajemen pembelajaran adalah proses menolong murid untuk mencapai pengetahuan, keterampilan, kemampuan dan pemahaman terhadap dunia disekitar mereka. Manajemen pembelajaran adalah proses pendayagunaan seluruh komponen yang saling berinteraksi (sumber daya 
pengajaran) untuk mencapai tujuan program pengajaran (Syafaruddin \& Nasution, 2005, hlm. 79).

Fungsi manajemen pembelajaran yaitu: perencanaan pengajaran, pengorganisasian pengajaran, kepemimpinan dalam kegiatan belajar mengajar dan evaluasi pembelajaran. Dalam menjalankan fungsi manajemen, sorang guru harus memanfaatkan sumber daya pengajaran (learning resouces) yang ada didalam kelas maupun diluar kelas (Syafaruddin \& Nasution, 2005, hlm. 79).

Fungsi manajemen pembelajaran yang pertama adalah perencanaan pembelajaran. Pengertian perencanaan itu sendiri adalah salah satu fungsi awal aktivitas manajemen dalam mencapai tujuan secara efektif dan efesien. Sedangkan pengertian rencana pembelajaran merupakan program kegiatan guna menentukan strategi yang disusun untuk menyiapkan target pada masa depan dengan tercapainya suatu tujuan (Syafaruddin \& Nasution, 2005, hlm. 91). Fungsi manajemen pembelajaran yang kedua adalah pengorganisasian pembelajaran. Menurut Davis, mengorganisir dalam pembelajaran adalah pekerjaan yang dilakukan seorang guru dalam mengatur dan menggunakan sumber belajar dengan maksud mencapai tujuan belajar dengan cara efektif dan efisien (Syafaruddin \& Nasution, 2005, hlm. 110). Organisasi dalam pembelajaran merupakan kegiatan untuk membagi suatu penetapan proses pendidik dan peserta didik dalam membagi tugas kerja untuk melaksanakan proses kegiatan pembelajaran.

Fungsi manajemen pembelajaran yang ke tiga adalah kepemimpinan pembelajaran. Mondy dan Premeaux menjelasakan bahwa kepemimpinan adalah mempengaruhi orang lain untuk melakukan apa yang diinginkan pemimpin untuk melakukan apa yang diinginkan pimpinan untuk mereka lakukan. Kepemimpinan dalam konteks pembelajaran adalah peran seorang guru menolong murid untuk mengembangkan kapasitas pembelajaran, yang memungkinkan aktivitas manajemen, struktur organisasi, sistem dan proses yang diperlukan untuk menangani kegiatan mengajar dan peluang belajar para murid secara maksimal (Syafaruddin \& Nasution, 2005, hlm. 122). Jadi, yang menjalankan kepemimpinan dalam pembelajaran ialah seorang guru, karena proses mempengaruhi murid agar mau belajar dengan sukarela dan senang memungkinkan tujuan pembelajaran dapat dicapai dengan baik. Dan fungsi manajemen pembelajaran yang terakhir yaitu evaluasi pembelajaran. Evaluasi pembelajaran merupakan proses sistematis untuk memperoleh informasi tentang keefektivan proses pembelajaran dalam membantu siswa mencapai tujuan pengajaran secara optimal. Dengan demikian evaluasi pembelajaran menetapkan baik buruknya proses dari kegiatan pembelajaran (Syafaruddin \& Nasution, 2005, hlm. 137).

Dari ke empat fungsi pembelajaran tadi, hal tersebut dapat diaplikasikan dalam proses manajemen pembelajaran Tahfidz Al-Qur'an. Karena saat ini banyak lembaga pendidikan Islam baik formal maupun non formal yang menyelenggarakan program Tahfidz Al-Qur'an. Pengertian Al-Qur'an itu sendiri menurut bahasa berasal dari kata qa-ra-a yang artinya membaca. Para ulama berbeda pendapat mengenai pengertian atau definisi tentang Al-Qur'an. Hal ini terkait sekali dengan masing-masing fungsi dari Al-Qur'an itu sendiri. Sedangkan menurut Istilah Al-Qur'an adalah kitab yang diturunkan kepada 
Rasulullah SAW, ditulis dalam mushaf, dan riwayatkan secara mutawatir tanpa keraguan (Anwar, 2004, hlm. 31).

Menghafal Al-Qur'an adalah suatu proses untuk menjaga dan memelihara Al-Qur'an diluar kepala (mengingat) dengan baik dan benar dengan syarat dan tata cara yang telah di tentukan (Fachrudin, 2017). Menghafal Alqur'an adalah langkah awal untuk memahami kandungan ilmu-ilmu Al-Qur'an yang dilakukan setelah proses membaca dengan baik dan benar (Al-Hafidz, 2005, hlm. 19).

Lembaga pendidikan Islam yang biasanya menyelenggarakan Tahfidz Al-Qur'an adalah Pondok Pesantren. Pondok berasal dari bahasa Arab "Funduq" yang memiliki arti tempat menginap, atau asrama. Adapun pesantren berasal dari bahasa Tamil, dari kata santri, diimbuhi awalan pe-dan akhiran-an yang berarti para penuntut ilmu. Sedangkan menurut istilah pondok pesantren merupakan suatu lembaga pendidikan Islam yang tradisional guna mempelajari, mendalami, memahami, menghayati serta mengamalkan ajaran Islam dengan memprioritaskan pentingnya moral keagamaan sebagai pendoman perilakunya (Zulhimma, 2013). Pesantren ialah sebuah asrama pendidikan Islam tradisional yang dimana para siswanya tinggal secara bersama dan mempelajari berbagai macam ilmu keagamaan dengan bimbingan seorang kyai (Herman, 2013).

Salah satu pondok pesantren yang menyelenggarakan Tahfidz Al-Qur'an adalah Pondok Pesantren Al-Hikamussalafiyyah di Kabupaten Sumedang. Pondok Pesantren Al-Hikamussalafiyyah merupakan lembaga pendidikan Islam non formal yang memiliki peran serta menjaga keaslian Al-Qur'an. Hal ini terbukti dengan adanya program tahfidz atau hafalan Al- Qur'an yang menjadi keunikan di Pondok Pesantren Al-Hikamussalafiyyah yaitu pembelajaran tahfidz dengan menggunakan metode talaqqi.

Metode talaqqi adalah menyetorkan atau memperdengarkan hafalan yang baru dihafal kepada seorang guru atau instruktur. Guru tersebut haruslah seorang hafidz Al-Qur'an, telah mantap agama dan ma'rifatnya, serta dikenal mampu menjaga dirinya (Sa'adulloh, 2010, hlm. 54). Talaqqi merupakan cara menyampaikan bacaan Al-Qur'an secara musyafahah (anak melihat gerak bibir guru secara tepat) yaitu berhadapan langsung dengan murid dalam posisi duduk dengan tenang dan nyaman, kemudian guru membimbing anak untuk mengulang-ulang ayat yang dibacakan dengan memperdengarkan kepada anak sampai anak benar-benar hafal (Susianti, 2016).

Pondok Pesantren Al-Hikamussalafiyyah merupakan lembaga yang bertujuan membimbing santri untuk cinta terhadap Al-Qur'an melalui proses belajar menghafalnya. Hal ini sesuai dengan salah satu visinya yaitu berjiwa Qur'ani. Sehingga Pondok Pesantren Al-Hikamussalafiyyah ini diidentikan dengan lembaga yang mencetak orang-orang yang melestarikan AI-Qur'an.

Setiap santri di Pondok Pesantren Al-Hikamussalafiyyah mempunyai kemampuan dan motivasi yang berbeda-beda dalam proses menghafal AlQur'an, karena pada kenyataannya mereka tidak hanya fokus menghafalkan AlQur'an saja tetapi mereka juga bersekolah formal, meskipun dalam kurikulum sekolah terdapat pembelajaran tahfidz. Melihat hal tersebut tentunya santri memiliki tanggung jawab menghafal Al-Qur'an dan sekolah. Pelaksanaannya siswa tetap diharapkan mampu menghafal AI-Qur'an secara lancar, dapat disetorkan dengan lantang dan memenuhi target hafalan yang telah ditentukan. 
Kegiatan sekolah pun dapat mereka ikuti dengan baik, bahkan ada beberapa santri yang melebihi target hafalannya dan sampai menjuarai lomba STQ, $\mathrm{MHQ}$, tingkat kabupaten, provinsi, dan nasional. Ketika santri mendapatkan prestasi yang bagus dan mendapatkan kemajuan hafalan AI-Qur'an yang baik, ini menunjukan santri berhasil dan sukses. Hal ini menjadi kebanggaan bagi ustadz dan ustadzah, karena prestasi yang selama ini di raih tidak terlepas dari sistem pembelajaran lembaga itu sendiri untuk mencetak para penghafal AlQur'an.

Tahapan pembelajaran Tahfidz Al-Qur'an di Pondok Pesantren AlHikamussalafiyyah mempunyai sistem yang mengutamakan pada makhorijul huruf, tahsin, bin-nazhar, dan tahfidz. Sistem tersebut menjadi tolak ukur santri untuk melanjutkan ke hafalan tahfidz berikutnya dan menjadi tahap awal dalam pembelajaran sebelum ke tahfidz, karena harus fasih terlebih dahulu dalam membacanya, makhorijul hurufnya, tajwidnya, dan lain-lain. Dalam pembelajaran tahfidz ini dibagi menjadi dua kelompok yaitu: pertama, kelompok yang sebelum masuk tahfidz atau masih melakukan pembelajaran membaca Al-Qur'an terlebih dahulu dengan memakai sistem makhorijul huruf, tahsin, dan bin-nazhar. Kedua, kelompok yang sudah masuk tahfidz, kelompok ini merupakan kelompok yang sudah dinilai mampu melakukan pembelajaran pada tahapan sebelumnya. Dalam proses pembelajaran tahfidz ini santri menghafal Al-Qur'an menggunakan metode talaqqi. Metode Talaqqi yaitu metode mengahafal Al-Qur'an dengan cara menyetorkan atau memperdengarkan hafalan yang baru dihafal kepada seorang guru atau instruktur. Guru tersebut haruslah seorang hafidz Al-Qur'an yang telah mantap agama dan ma'rifatnya (Sa'adulloh, 2010, hlm. 54). Setelah itu santri tinggal murajaah (mengulang) agar tetap terjaga hafalannya.

Berdasarkan fenomena diatas sampai sejauh ini muncul masalah yang terjadi di Pondok Pesantren Al- Hikamussalafiyah, yaitu adanya manajemen pembelajaran Tahfidz Al-Qur'an berbasis metode Talaqqi yang mengakibatkan santri mencapai target hafalannya. Berdasarkan identifikasi masalah diatas, hal tersebut menarik untuk diteliti lebih lanjut. Maka dirumuskan dalam sebuah judul Manajemen Pembelajaran Tahfidz Al-Qur'an Berbasis Metode Talaqqi (Penelitian di Pondok Pesantren Al-Hikamussalafiyyah Sumedang).

\section{METODE PENELITIAN}

Peneltian ini menggunakan pendekatan kualitatif. Pendekatan kualitatif adalah mengungkapkan fakta yang ada kemudian dijelaskan secara deskriptif dengan kata-kata dan uraian. Penelitian ini menggambarkan secara objektif dan apa adanya mengenai manajemen pembelajaran Tahfidz Al-Qur'an berbasis metode talaqqi di Pondok Pesantren Al-Hikamussalafiyyah. Tujuan penelitian kualitatif pada umumnya mencakup informasi tentang fenomena utama yang dieksplorasi dalam penelitian, partisipan penelitian, dan lokasi penelitian (Creswell, 2017, hlm. 164).

Adapun metode yang digunakan dalam penelitian ini ialah metode deskriptif. Metode deskriftif adalah metode yang digunakan untuk menggambarkan tentang realita manajemen pembelajaran Tahfidz Al-Qur'an berbasis metode talaqqi di Pondok Pesantren Al-Hikamussalafiyyah. 
Data primer didapatkan melalui wawancara terhadap pimpinan Pondok Pesantren K.H. Mohammad Aliyudin dan Kepala Tahfidz Al-Qur'an yaitu K.H. Sa'adulloh sebagai key informan diikuti dengan snow ball process yaitu Ustadzah Ummi, Ustadz Ayi, Ustadz Syarif, Ustadzah Ifah, Ustadz yang diharapkan dapat memberikan keterangan yang benar mengenai manajemen pembelajaran Tahfidz Al-Qur'an berbasis metode talaqqi. Data sekunder berupa wawancara terhadap santri dan data penunjang berupa dokumen, arsip, buku, foto, dan yang lainnya yang berkaitan dengan manajemen pembelajaran Tahfidz Al-Qur'an berbasis metode talaqqi di Pondok Pesantren AlHikamussalafiyyah.

\section{HASIL DAN PEMBAHASAN}

Pondok Pesantren Al-Hikamussalafiyyah merupakan pondok pesantren yang bernaung dibawah Yayasan Pendidikan Islam Mohammad Aliyuddin. Pondok Pesantren Al-Hikamussalafiyyah merupakan pesantren yang memfokuskan pada Tahfidz Al-Qur'an, yang dipimpin oleh Al-Mukkarram K.H. Mohammad Aliyuddin. Pondok Pesantren Al-Hikamussalafiyyah berada di Jalan Sukamantri No 85 RT 03 RW 04 Kecamatan Tanjung Kerta Kabupaten Sumedang Provinsi Jawa Barat. Pondok Pesantren Al-Hikamussalafiyyah berawal dari pengajian Al-Qur'an dan Kitab Kuning yang diselenggarakan di rumah K.H Mohammad Aliyuddin bersama masyarakat sekitar, kemudian pada bulan Juli 1984 pondok pesantren ini diresmikan oleh pemerintah (Kementerian Agama RI). Setelah peresmian Pondok Pesantren Al-Hikamussalafiyyah pun mengalami kemajuan yang signifikan, jumlah santri semakin meningkat dan bermunculan dari berbagai kabupaten tetangga, yaitu Subang, Majalengka, dan Bogor. Untuk memenuhi kebutuhan santri mengenai pendidikan formal, yayasan mendirikan MTs Plus Al-Hikamussalafiyyah dan MA Plus AlHikamussalafiyyah pada tahun 2005. Semakin berkembangnya sarana dan prasarana pendidikan di Pondok Pesantren Al-Hikamussalafiyyah menjadikan pembelajaran tahfidz berjalan dengan Kondusif sehingga berdampak pada prestasi yang diraih oleh santri.

\section{Perencanaan Pembelajaran Tahfidz Al-Qur'an Berbasis Metode Talaqqi}

Perencanaan program tahfidz di Pondok Pesantren AlHikamussalafiyyah berada dibawah yayasan Pendidikan Islam Mohammad Aliyuddin. Konsep pembelajaran program tahfidz Al-Qur'an berada dibawah tanggung jawab K.H Sa'dulloh (alumni Institut PTIQ Jakarta), berdasarkan pertimbangan bahwa perlu diadakannya pembelajaran khusus Al-Qur'an seperti yang dilakukan dibeberapa pesantren Tebuireng Jombang, dll. Perencanaan awal yang dibuat yaitu: (1) menentukan target hafalan santri; (2) menentukan strategi dan metode pembelajaran; (3) menentukan program kegiatan pembelajaran; (4) menentukan jadwal dan waktu pembelajaran.

\section{Menentukan Target Hafalan Santri}

Target utama dalam proses Tahfidz Al-Qur'an di Pondok Pesantren AlHikamussalafiyyah yaitu 30 juz. Untuk mencapai target tersebut ustadz/ustadzah mengadakan 3 tahap seleksi, yaitu: (1) santri yang mememiliki motivasi untuk menghafal dengan berkomitmen terhadap ustadz/ustadzah; (2) 
tes kemampuan baca tulis Al-qur'an; (3) mengukur kemampuan layak atau tidak menghafal Al-Qur'an dengan indikator lulus baca tulis AI-Qur'an serta menguasai makharijul huruf dan tajwid.

Tidak hanya itu, di Pondok Pesantren Al-Hikamussalafiyyah terdapat target-target hafalan lainnya yang disesuaikan dengan kemampuan santri dalam proses pembelajaran Tahfidz Al-Qur'an. Santri dapat dikategorikan sesuai dengan target hafalan ya ng akan di tempuhnya, diantaranya: kelas satu, mampu menghafal juz 30 dan surat pilihan; kelas dua, mampu menghafal 1-5 juz; kelas tiga, mampu menghafal 5-10 juz; serta tahasus, diharapkan mampu menghafal 15-30 juz.

\section{Menentukan Strategi Dan Metode Pembelajaran}

Santri di Pondok Pesantren Al-Hikamussalafiyyah sudah tidak ada yang pulang-pergi dari rumahnya (santri kalong), santri di wajibkan untuk mondok atau tinggal di pesantren. Karena hal tersebut dapat menunjang kemampuan santri yang mendapatkan bimbingan selama 24 jam di pondok pesantren. Adapun metode pembelajaran Tahfidz Al-Qur'an di Pondok Pesantren AlHikamussalafiyyah lebih menekankan pada metode talaqqi atau memperdengarkan/menyetorkan yang dilakukan sesuai jadwal yang sudah ditetapkan.

\section{Program kegiatan Pembelajaran Tahfidz Al-Qur'an}

Program Tahfidz Al-Qur'an merupakan program unggulan di Pondok Pesantren Al-Hikamussalafiyyah, untuk melaksanakan program Tahfidz AlQur'an santri harus melaksanakan beberapa tahapan yaitu: makharijul huruf, tajwid, tahsinul Qur'an, kemudian tahfidz. Kegiatan pembelajaran tahfidz dilakukan 3 kali dalam sehari, yaitu: ba'da Subuh dan ba'da Dzuhur, materi ziyadah (menambah hafalan); ba'da Isya, materi murojaah (mengulang hafalan yang sudah dihafal).

\section{Jadwal dan Waktu Pembelajaran Tahfidz Al-Qur'an}

Santri di Pondok Pesantren Al-Hikamussalafiyyah diwajibakan tinggal di dalam pondok dan mengikuti seluruh ketentuan yang berada di pondok, termasuk kegiatan pembelajaran tahfidz; pengajian kitab kuning yang meliputi fiqh, akhlak, tafsir; dan kegiatan yang sudah menjadi budaya di Pondok Pesantren Al-Hikamussalafiyyah ini.

Penentuan jadwal kegiatan pembelajaran Tahfidz Al-Qur'an di Pondok Pesantren Al-Hikamussalafiyyah terdapat perbedaan jadwal antara santri putra dan santri putri. Adapun jadwal kegiatan harian santri putra adalah sebagai berikut:

Tabel 1. Jadwal Kegiatan Harian Santri Putra

\begin{tabular}{cl}
\hline Waktu & Kegiatan \\
\hline \multirow{2}{*}{$\mathbf{0 4 . 0 0 - 0 5 . 3 0}$} & Sholat Subuh Berjama'ah \\
\cline { 2 - 2 } & Persiapan Setoran Al-Qur'an \\
\hline $\mathbf{0 5 . 3 0 - 0 8 . 3 0}$ & Setoran Tahfidz Al-Qur'an \\
\hline $\mathbf{0 8 . 3 0 - 1 0 . 0 0}$ & Istirahat, Sholat, Makan \\
\hline
\end{tabular}




\begin{tabular}{ll}
\hline $\mathbf{1 0 . 0 0 - 1 1 . 0 0}$ & Setoran Tahfidz Al-Qur'an \\
\hline $\mathbf{1 1 . 0 0 - 1 2 . 0 0}$ & Istirahat \\
\hline $\mathbf{1 2 . 0 0 - 1 2 . 3 0}$ & Sholat Dzuhur Berjama'ah \\
\hline $\mathbf{1 3 . 0 0 - 1 7 . 3 0}$ & Kegiatan Madrasah \\
\hline $\mathbf{1 7 . 3 0 - 1 8 . 0 0}$ & Istirahat, makan \\
\hline $\mathbf{1 8 . 0 0 - 1 9 . 2 0}$ & Setoran Tahfidz Al-Qur'an \\
\hline $\mathbf{1 9 . 2 0 - 2 0 . 0 0}$ & Sholat Isya Berjama'ah \\
\hline $\mathbf{2 0 . 0 0 - 2 2 . 0 0}$ & Pengajian Kitab Kuning \\
\hline $\mathbf{2 2 . 0 0 - 2 3 . 0 0}$ & Bimbingan Belajar \\
\hline $\mathbf{2 3 . 0 0 - 0 4 . 0 0}$ & Istirahat malam \\
\hline
\end{tabular}

Seperti yang dapat kita lihat, kegiatan setiap hari santri putra dimulai dari pukul 04.00 untuk bangun pagi dan dilanjutkan dengan persiapan sholat Subuh berjamaah dan setelahnya dilanjutkan dengan kegiatan persiapan setoran hafalan Al-Qur'an. Dan kegiatan terakhir yaitu mulai pukul 23.00 untuk istirahat malam setelah selesai bimbingan belajar. Adapun jadwal kegiatan harian santri putri adalah sebagai berikut.

Tabel 2. Jadwal Kegiatan Harian Santri Putri

\begin{tabular}{|c|c|}
\hline Waktu & Kegiatan \\
\hline \multirow{3}{*}{ 04.00-06.30 } & Sholat Subuh Berjama'ah \\
\hline & Setoran Tahfidz Al-Qur'an \\
\hline & Sorogan Kitab Kuning \\
\hline 06.00-07.00 & Persiapan Kegiatan Madrasah \\
\hline 07.00-09.40 & Kegiatan Madrasah \\
\hline 09.40-10.00 & Istirahat, Makan \\
\hline $10.00-13.15$ & Kegiatan Madrasah \\
\hline \multirow{2}{*}{$14.15-16.30$} & Setoran Tahfidz Al-Qur'an \\
\hline & Sholat Asar Berjama'ah \\
\hline $16.30-18.00$ & Istirahat-Pasaran Kitab Kuning \\
\hline $18.00-18.30$ & Sholat Magrib berjama'ah \\
\hline \multirow{2}{*}{$18.30-19.30$} & Setoran Tahfidz Al-Qur'an \\
\hline & Sholat Isya Berjama'ah \\
\hline $19.30-21.30$ & Pengajian Kitab Kuning \\
\hline $21.30-22.30$ & Bimbingan belajar \\
\hline 22.30-04.00 & Istirahat Malam \\
\hline
\end{tabular}

Sama halnya seperti kegiatan santri putra, kegiatan pertama santri putri juga dimulai pukul 04.00 untuk bangun pagi dan melakukan persiapan untuk melaksanakan shalat Subuh berjamaah. Namun kegiatan terakhir santri putri lebih cepat 30 menit, yaitu berakhir pada pukul 22.30 untuk memulai istirahat malam setelah selesai melakukan kegiatan bimbingan belajar.

\section{Pengorganisasian Pembelajaran Tahfidz Al-Qur'an Berbasis Metode Talaqqi}

Pengorganisasian merupakan kegiatan pembagian tugas yang akan dilaksanakan. Pengorganisasian pembelajaran Tahfidz Al-Qur'an Pondok 
Pesantren Al-Hikamussalafiyyah dimulai dengan pembagian tugas pembinaan dan bimbingan santri Tahfidz Al-Qur'an terhadap ustadz/ustadzah serta mekanisme pembelajaran Tahfidz Al-Qur'an.

Ustadz/ustadzah Tahfidz Al-Qur'an diberi tugas untuk menjadikan santri istiqomah dalam menghafal Al-Qur'an, mendidik santri agar bisa, membimbing dalam proses pembelajaran, dan memotivasi santri agar santri selalu bersemangat dalam menghafal Al-Qur'an. Adapun ustadz/ustadz madrasah bertugas untuk membimbing santri dalam proses pembelajaran kitab kuning.

Pelaksanaan pembelajaran Tahfidz Al-Qur'an di Pondok Pesantren AlHikamussalafiyyah dilakukan secara sistematis agar mencapai hasil maksimal. Ustadz/ustadzah harus kompak agar bisa mengendalikan santri dengan terarah. Mekanisme pembelajaran Tahfidz di Pondok Pesantren AlHikamussalafiyyah terdapat beberapa tahapan sebagai berikut: tahap pertama, seluruh santri diwajibkan sudah menguasai makharijul huruf (tempat keluarnya huruf hijaiyah) dan tajwid (ilmu tata cara membaca Al-Qur'an), serta mengikuti Tahsin Al-Qur'an untuk memperbaiki bacaan Al-Qur'an. Tahap kedua, santri mengikuti program Binadzar (melihat). Kemudian jika sudah diniatkan ingin tahfidz, santri mulai menghafal dari Juz 1-5 kemudian di hafal dan disetorkan kepada ustadz/ustadzah. Tahap ketiga, yaitu Tahfidz (menghafal), dimana santri sudah menguasai hafalan. Santri dituntut melanjutkan hafalannya secara istiqomah dengan cara Talaqqi (menyetorkan/memperdengarkan hafalan) setiap harinya kepada ustadz/ustadzah.

\section{Kepemimpinan Pembelajaran Tahfidz Al-Qur'an Berbasis Metode Talaqqi}

Proses pembelajaran Tahfidz Al-Qur'an di Pondok pesantren AlHikamussalafiyyah tidak luput dari kepemimpinan seorang ustadz/ustadzah. Kepemimpinan pembelajaran dilakukan pada saat pelaksanaan pembelajaran, dimana pelaksanaan pembelajaran meliputi pengelolaan kelas dan kegiatan pembelajaran.

\section{Pengelolaan Kelas}

Pengelolaan kelas merupakan suatu usaha yang dilakukan guru (ustadz) secara optimal agar terlaksananya kegiatan belajar mengajar yang diharapkan (Warsono, 2016). Kepemimpinan seorang ustadz/ustadzah sangat berperan penting dalam mengelola kelas pembelajaran Tahfidz Al-Qur'an di Pondok Pesantren Al-Hikamussalafiyyah ini. Dalam pelaksanaannya, ustadz/ustadzah mampu mengarahkan santri agar menaati tata tertib saat proses pembelajaran berlangsung, salah satunya santri tidak boleh terlambat masuk kelas dan tidak membuat kegaduhan di dalam kelas.

\section{Kegiatan Pembelajaran}

Kegiatan pembelajaran terdiri dari kegiatan pendahuluan, kegiatan inti, dan kegiatan penutup. Dalam kegiatan pendahuluan ustadz/ustadzah akan membuka pembelajaran dengan membaca do'a serta sholawat. Do'a dipanjatkan kepada Allah SWT atas rasa syukur masih diberi nikmat iman, Islam serta kesehatan untuk mengikuti proses pembelajaran. Serta sholawat menunjukan pengharapan bersama agar melalui sholawat Allah SWT mempermudah santri dalam proses menghafal. Kemudian seluruh santri 
membaca do'a sebelum belajar yang dipimpin oleh ustadz/ustadzah, dimana hal ini menunjukan bahwa sepintar apapun santri jika dalam dirinya tertanam kesombongan maka mungkin saja akan mendapat kesulitan dalam proses menghafal Al-Qur'an. Do'a ini dimaksudkan agar santri menyadari bahwa mereka hanyalah hamba Allah SWT yang lemah.

Kepemimpinan seorang guru tentu erat kaitannya dengan proses menggerakan (memotivasi) santri, agar santri bersemangat dalam mencapai tujuannya yaitu menjadi seorang hafidz/hafidzah. Motivasi dilakukan mengingat kondisi seseorang tidak selalu stabil, baik fisik maupun psikis. Maka dorongandorongan semangat ini sangat diperlukan. Ketika proses pembelajaran Tahfidz Al-Qur'an berlangsung dan santri keliru dalam proses belajarnya, ustadz/uztadzah langsung membantu mengarahkan hafalannya, membimbing dengan sabar dan memberi motivasi agar santri mencapai target hafalannya. Salah satu cara ustadz/ustadzah memberi motivasi adalah dengan memberikan cerita mengenai keutamaan penghafal Al-Qur'an. Dengan itu santri akan tergugah dan kembali bersemangat untuk melanjutkan Tahfidz Al-Qur'annya.

Setelah memberikan motivasi, ustadz/ustadzah akan memimpin santri untuk muraja'ah (mengulang hafalan). Muraja'ah ini dilakukan ba'da isya dimana santri mengulang materi tahfidz pada pertemuan sebelumnya (ba'da subuh dan ba'da dzuhur). Dalam pembelajaran Tahfidz Al-Qur'an, muraja'ah merupakan kegiatan yang tidak boleh dilewatkan, karena menghafal tanpa muraj'ah maka hafalan akan dengan mudah hilang dan menyebabkan lupa. Karena muraja'ah berperan untuk menguatkan hafalan yang sudah dihafal.

Kegiatan inti dari pembelajaran Tahfidz Al-Qur'an di Pondok Pesantren Al-Hikamussalafiyyah ini dimulai dengan tahsin (memperbaiki bacaan) AlQur'an kemudian masuk ke tajwid beserta makhorijul huruf melalui bimbingan ustadz/ustadzah. Kemudian santri belajar Tahfidz Al-Qur'an dengan cara talaqqi yaitu memperdengarkan hafalan Al-Qur'an yang telah dihafal secara langsung di hadapan ustadz/ustadzah. Kegiatan talaqqi ini dilakukan secara bergiliran sebanyak 5 sampai 6 orang.

Pada kegiatan penutup, seluruh santri kembali dengan tertib ketempat duduk masing-masing. Setelah itu ustadz/ustadzah akan menyampaikan beberapa refleksi dari kegiatan pembelajaran tersebut. Seperti hal-hal yang menghambat dalam proses pembelajaran, dan hal-hal yang mendukung dalam proses pembelajaran. Diakhir, ustadz/ustadzah akan memimpin do'a Khotmil Qur'an tanda pembelajaran sudah selesai. Hal ini bertujuan untuk mendidik santri agar dalam proses menghafal AI-Qur'an diawali dan diakhiri dengan do'a.

\section{Evaluasi Pembelajaran Tahfidz Al-Qur'an Berbasis Metode Talaqqi}

Evaluasi pembelajaran Tahfidz Al-Qur'an di Pondok Pesantren AlHikamussalafiyyah yaitu dilakukan dengan cara melihat hasil belajar santri serta kemampuan yang dimiliki santri. Indikator yang telah ditentukan pihak Pondok Pesantren Al-Hikamussalafiyyah untuk melihat kemampuan santri disesuaikan dengan kelasnya masing-masing. Adapun untuk kelas satu kemamampuan yang harus di capai yaitu bisa membaca AI-Qur'an dengan baik dan benar, mengetahui ilmu tajwid, serta mengahafal juz 30 dan surat pilihan. Kelas dua, membaca Al-Qur'an sudah baik dan benar, menguasai ilmu tajwid beserta dalilnya, serta menghafal 1-5 juz. Kelas tiga, indikator yang dicapai yaitu 
membaca Al-Qur'an dengan baik dan benar, menguasai tajwid beserta dalilnya, sifatul huruf, serta menghafal 5-10 juz. Sedangkan takhosus (santri yang tidak bersekolah) indikator yang dicapai yaitu membaca Al-Qur'an dengan baik dan benar, menguasai tajwid beserta dalilnya, sifatul huruf, serta menghafal 15-30 juz.

Selama proses pembelajaran berlangsung, para santri diberikan bimbingan oleh ustadz/ustadzah untuk terus memperbaiki bacaan Al-Qur'an dan terus menambah hafalannya. Bimbingan yang diberikan ustadz/ustadzah tidak dibedakan/dikelompokan, melainkan sama terhadap semua santri yang berada di pondok pesantren Al-Hikamussalafiyyah.

Untuk mengoptimalkan hafalan para santri dilakukan muraja'ah yang dilakukan ba'da isya, agar santri selalu mengingat hafalan sebelumnya. Dan dilakukan evaluasi bulanan yang berbetuk sima'an (diperdengarkan hafalan AlQur'an dalam waktu satu hari) waktunya pada Kamis Wage.

\section{SIMPULAN}

Perencanaan pembelajaran Tahfidz Al-Qur'an di Pondok Pesantren AlHikamussalafiyyah berada dibawah tanggung jawab K.H. Sa'adulloh, dimana perencanaan awal yang dibuat yaitu: pertama, menentukan target hafalan santri; kedua, menentukan strategi dan metode pembelajaran; ketiga, menentukan program kegiatan pembelajaran; keempat, menentukan jadwal dan waktu pembelajaran. Perencanaan pembelajaran dilaksanakan secara matang, terlihat dari kerjasama antara pihak Pondok Pesantren Al-Hikamussalafiyyah dengan lembaga pendidikan yang berada dibawah naungan Yayasan Mohammad Aliyudin. Dimana pembelajaran Tahfidz Al-Qur'an dimasukan kedalam kurikulum sekolah, salah satunya terdapat mata pelajaran Tahfidz AlQur'an satu kali dalam seminggu.

Pengorganisasian pembelajaran Tahfidz Al-Qur'an di Pondok Pesantren Al-Hikamussalafiyyah dilaksanakan untuk mengetahui struktur dan tugas dari ustadz/ustadzah dalam melaksanakan tanggung jawab pembinaan dan bimbingan terhadap para santri. Serta mekanisme pembelajaran yang dilakukan oleh ustadz/ustadzah dimaksudkan agar santri belajar secara terarah.

Kepemimpinan pembelajaran Tahfidz Al-Qur'an di Pondok Pesantren AlHikamussalafiyyah dilakukan ustadz/ustadzah pada saat pelaksanaan pembelajaran. Hal tersebut dilakukan agar pembelajaran berjalan secara kondusif dan tujuan dari pembelajaran tercapai sesuai dengan yang diharapkan, pelaksanaan pembelajaran terdiri dari: pengelolaan kelas dan kegiatan pembelajaran yang meliputi kegiatan pendahuluan, kegiatan inti dan kegiatan penutup.

Evaluasi pembelajaran Tahfidz Al-Qur'an di Pondok Pesantren AlHikamussalafiyyah terlihat dari hasil belajar santri serta kemampuan yang dimiliki santri. Kemampuan santri disesuaikan dengan kelasnya masingmasing, hal tersebut merupakan indikator yang telah ditentukan oleh pihak Pondok Pesantren Al-Hikamussalafiyyah.

\section{REFERENSI}

Al-Hafidz, A. W. (2005). Bimbingan Praktis Menghafal Al-Qur'an. Jakarta: Bumi Aksara. 
Anwar, R. (2004). Pengantar Ulumul Qur'an. Bandung: Pustaka Setia.

Creswell, J. (2017). Research Design (Pendekatan Metode Kualitatif, Kuantutatif, dan Campuran). Yogyakarta: Pustaka Pelajar.

Fachrudin, Y. (2017). Pembinaan Tahfizh Al-Quran Di Pesantren Tahfizh Daarul Qur'an Tangerang. KORDINAT: Jurnal Komunikasi Antar Perguruan Tinggi Agama Islam, 16(2), 325-348.

DOI: $10.15408 /$ kordinat.v16i2.6445

Herman. (2013). Sejarah Pesantren di Indonesia. Jurnal Al-Ta'dib, 6(2), 145158. tadib/article/view/311/301

http://ejournal.iainkendari.ac.id/index.php/al-

Rukajat, A. (2018). Manajemen Pembelajaran. Yogyakarta: Deepublish.

Sa'adulloh. (2010). 9 Cara Praktis Menghafal Al-Qur'an. Jakarta: Gema Insani.

Susianti, C. (2016). Efektivitas Metode Talaqqi Dalam Meningkatkan Kemampuan Menghafal AI-Qur'an Anak Usia Dini. Tunas Siliwangi, 2(1), $1-19$.

http://e-journal.stkipsiliwangi.ac.id/index.php/tunas-

siliwangi/article/download/305/226

Syafaruddin, \& Nasution, I. (2005). Manajemen Pembelajaran. Jakarta: Quantum Teaching.

Warsono, S. (2016). Pengelolaan Kelas dalam Meningkatkan Belajar Siswa. Manajer Pendidikan: Jurnal IImiah Manajemen Pendidikan Program Pascasarjana, 10(5), 469-476.

https://ejournal.unib.ac.id/index.php/manajerpendidikan/article/view/1298 $/ 109$

Zulhimma. (2013). Dinamika Perkembangan Pondok Pesantren di Indonesia. Jurnal Darul 'Ilmi, 01(02), 165-181. 